\title{
RESTORING NATIVE FISH POPULATIONS IN AUSTRALIA'S MURRAY DARLING BASIN
}

\author{
J. MAROHASY \& J. ABBOT \\ Centre for Plant and Water Science, CQ University, Noosa, Queensland, Australia.
}

\begin{abstract}
In 2003, the Australian government launched The Native Fish Strategy for the Murray Darling Basin 20032013 with the objective of restoring native fish populations in the Murray Darling Basin to $60 \%$ of their of pre-European (before 1788) settlement levels. Ten years on, there is no evidence that native fish populations show any sign of recovery, despite the Millennium drought breaking and significant government expenditure including the buyback of irrigation licences to increase in-streamflow and facilitate the watering of adjacent forests and wetlands. We review the native fish strategy, considering the five priority interventions originally identified. We conclude that more freshwater is unlikely to be effective at restoring native fish populations unless three additional issues are addressed: cold-water pollution, predation from introduced salmonids and the damming of the estuary. Unfortunately, however, these contentious issues are neither identified nor discussed in the new official planning document.

Keywords: Native fish, Murray River, cold-water pollution, estuary, salmonids.
\end{abstract}

\section{INTRODUCTION}

The Murray Darling catchment, also known as the Murray Darling Basin (MDB), drains an area of over one million square kilometres in south-eastern Australia. The MDB includes the Australian Alps that provide reliable snow melt, and once arid plains that now produce significant quantities of food and fibre, extending to the Coorong and Lower Lakes that face the Southern Ocean (Fig. 1). Significant water infrastructure development, providing water diversions for irrigated agriculture, has occurred in the MDB, resulting in a reduction in the average annual quantity of water that flows out to sea, approximately from 13,000 GL (gigalitres) to 5,000 GL [1]. Such statistics, highlighting the reduction in end-of-system flow, have been combined with claims that rainfall has declined due to climate change. This environmental campaigning has driven legislative change, resulting in policies and plans that place a premium on the need for more environmental water and the redistribution of water from agriculture to the environment.

In Australia, agriculture is not seen as part of the environment, but as an activity in competition with the natural environment, particularly for available water resources. The redistribution of water from agriculture is variously described as improving environmental outcomes, increasing environmental water and environmental waterings.

The most significant recent relevant legislative change was the passing of the Commonwealth Water Act 2007 requiring the Murray Darling Basin Authority (MDBA) to develop a Basin Plan. This plan gives effect to international agreements and establishes a long-term adaptive management framework for the Basin's water resources. The plan that became legislation in November 2012 specifies a maximum sustainable quantity of water that can be used for irrigated agriculture. Schedule 1 of The Plan refers to the serious decline in the distribution and abundance of native fish as a reflection of the continuing poor state of the river system and the impacts of human use. This is despite significant government funding since 2002 to oversee the development and implementation of The Native Fish Strategy for the Murray-Darling Basin 2003-2013 [2], henceforth referred to as The Strategy. This strategy was based on many of the same assumptions underpinning the new Basin Plan and administered by the same authority, the MDBA.

(C) 2015 WIT Press, www.witpress.com

ISSN: 1743-7601 (paper format), ISSN: 1743-761X (online), http://journals.witpress.com DOI: $10.2495 /$ SDP-V10-N4-487-498 


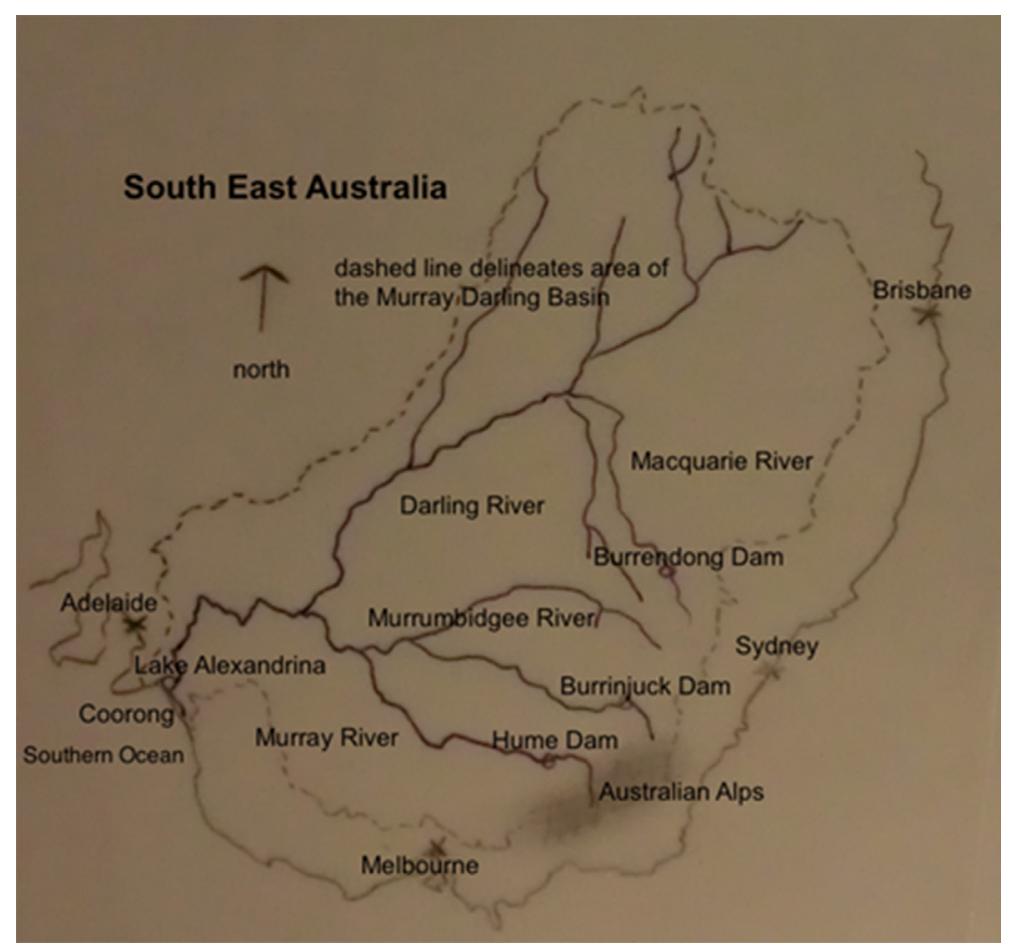

Figure 1: Murray Darling Basin showing key locations.

The Strategy, now superseded by the Basin Plan, explained that only through a combination of interventions could native fish communities be restored to $60 \%$ of pre-European (before 1788) levels. The Strategy also detailed how specific interventions alone, and in combination, could make a significant positive impact. Several of the interventions have been successfully completed and the amount of water recovered for the environment is now more than double the highest reference value of 1,500 GL annually that was proposed in April 2002 when The Strategy was being developed. Edition 34 of RipRap, a publication of the Australian River Restoration Centre, details many of the achievements of The Strategy. The many and varied articles in this publication laud The Strategy as providing a coordinated and scientific approach to the rehabilitation of fish populations. But, it is also stated that native fish populations are still in decline, and remain at only about $10 \%$ of estimated levels before European settlement [3]. This is the same percentage estimated in 2003, when The Strategy was launched.

In a conference paper, we reviewed implementation of the five interventions listing in The Strategy [4]. Analysis is extended in this paper to consider key assumptions underpinning the Basin Plan and to identify and highlight the remaining obstacles to conservation and restoration of native fish species in the Murray Darling. We conclude that if native fish populations are to be restored, contentious issues with a political dimension will need to be addressed. So far, the value of salmonids as a sport-fish and in aquaculture has overshadowed consideration of their negative impact on native fish populations and probably prevented the implementation of those aspects of The Strategy intended to address the issue of cold-water pollution. The other important contentious issue that was first ignored 
in The Strategy, and now also ignored in the Basin Plan, is that of restoration of the Murray River's estuary that was destroyed with the construction of sea dykes in the 1930s.

\section{REVIEW OF THE STRATEGY}

The Strategy explained that it seeks to target the causes as well as the symptoms of declining native fish populations and to focus on 'long-term rehabilitation rather than restoration' [2]. The Strategy provided a '10-year framework' building on the principles of a plan first developed in 1991, Fish Management Plan for the Murray River. The Strategy explained that only through a combination of interventions could native fish communities be restored to $60 \%$ of pre-European levels.

These five interventions, also referred to as priority works, are considered, with particular reference to Murray cod, Maccullochella peelii. This species is endemic to the Murray Darling and is one of the largest freshwater fish in the world reaching a highest recorded weight of $113.6 \mathrm{~kg}$ and an age estimate between 74 and 114 years. Murray cod was once part of a significant commercial fishery. However, there are currently no commercial fishing licences for Murray cod in Australia. The wild catch industry had ceased by 2004 in all Australian states following intense lobbying from recreational fishers and environmentalists.

\subsection{Habitat restoration}

The Strategy explained that through habitat restoration alone, native fish populations could be restored to $25 \%$ of pre-European levels. The Strategy stated: 'A diversity of habitats is needed for a diversity of species and life stages. In-stream and riparian habitats within the Basin have been severely degraded by factors such as river desnagging (removal of dead tree trunks and branches), loss of wetland, floodplain and river connectivity, bank erosion and sedimentation'.

An initial focus of The Strategy was resnagging $194 \mathrm{~km}$ of river immediately downstream of Hume dam with 4,500 new snags (logs with embedded microchips). Seven years of data collection suggests that this effort has resulted in the migration of native fish into this area, including Murray cod. However, it is unclear whether there has been successful breeding of Murray cod in this stretch of river [5]. In fact, given the cold-water pollution issues (discussed in Section 2.5), the resnagging of this stretch of the river could have caused net migration of Murray cod into an area unsuitable for reproduction.

In the northern catchment, there have been many 'Demonstration Reaches' established with work in the Namoi, for example, including the reintroduction of 300 snags, 5,700 aquatic plants, 9,000 native trees and shrubs, $33.4 \mathrm{~km}$ of woody weed management, $33.5 \mathrm{~km}$ of riparian fencing, installing 20 off-stream watering points and 8 in-stream gully and erosion protection works [6].

\subsection{Environmental flows}

The Strategy explains that environmental flows alone could return native fish to $35 \%$ of their preEuropean level, yet no benefit has been reported from this intervention. Environmental flows are a focus of the new Basin Plan that has as its target the recovery of 2,750 GL. In 2002, at the time The Strategy was being developed, the environmental flow target was much more modest. Indeed, in April 2002, when the Murray-Darling Basin Ministerial Council called for social, economic and ecological assessments of the costs and benefits of returning additional environmental water to the River Murray, three flow volumes were chosen - 350, 750 and 1,500 GL per year - as 'reference points' for assessment. Significant lobbying underpinned by a group sponsored by the 
World Wide Fund for Nature resulted in the higher final target of 2,750 GL being adopted in the new Basin plan.

Adoption of the higher target was aided by claims that because of human-induced climate change, there was an overall decline in rainfall in the MDB. This decline, however, is not obvious in the official rainfall data and the total annual rainfall during 2010 was the highest on record (Fig. 2).

As on 30th September 2012, the MDBA reported that the water purchase programme had already secured entitlements that will deliver on average 1,094 GL. This quantity of water in September 2011 had a market value between $\mathrm{A} \$ 0.8$ billion and $\mathrm{A} \$ 2$ billion ( $€ 0.6$ to $€ 1.6$ billion) depending on where in the MDB it was purchased.

The MDBA has also reported that more than 1,327 GL of Commonwealth Environmental Water has been delivered. In October 2005, the Victorian government reported that 513 GL of water was delivered into the Barmah-Millewa, red gum forest in one watering, 'triggering large reproductive events in important native fish species such as golden perch and the threatened silver perch'.

Environmental waterings are not, however, always beneficial to native fish species because the inundation of forested floodplains can cause blackwater events that have resulted in massive fish kills. Blackwater is the name given to water flooding out of forested areas that is high in dissolved organic carbon, which when rapidly consumed by microbes can lead to extremely low levels of dissolved oxygen (hypoxia) with drastic consequences for native fish species. For example, in late 2010, when widespread heavy rainfall and flooding occurred throughout much of the southern Murray-Darling, up to 2,000 km of the Murray River was affected by blackwater. A study of the impact of this event in the Central Murray Valley concluded that affected sites had: 'significantly higher abundances of emerged Murray crayfish that were vulnerable to desiccation, predation and exploitation; large numbers of dead

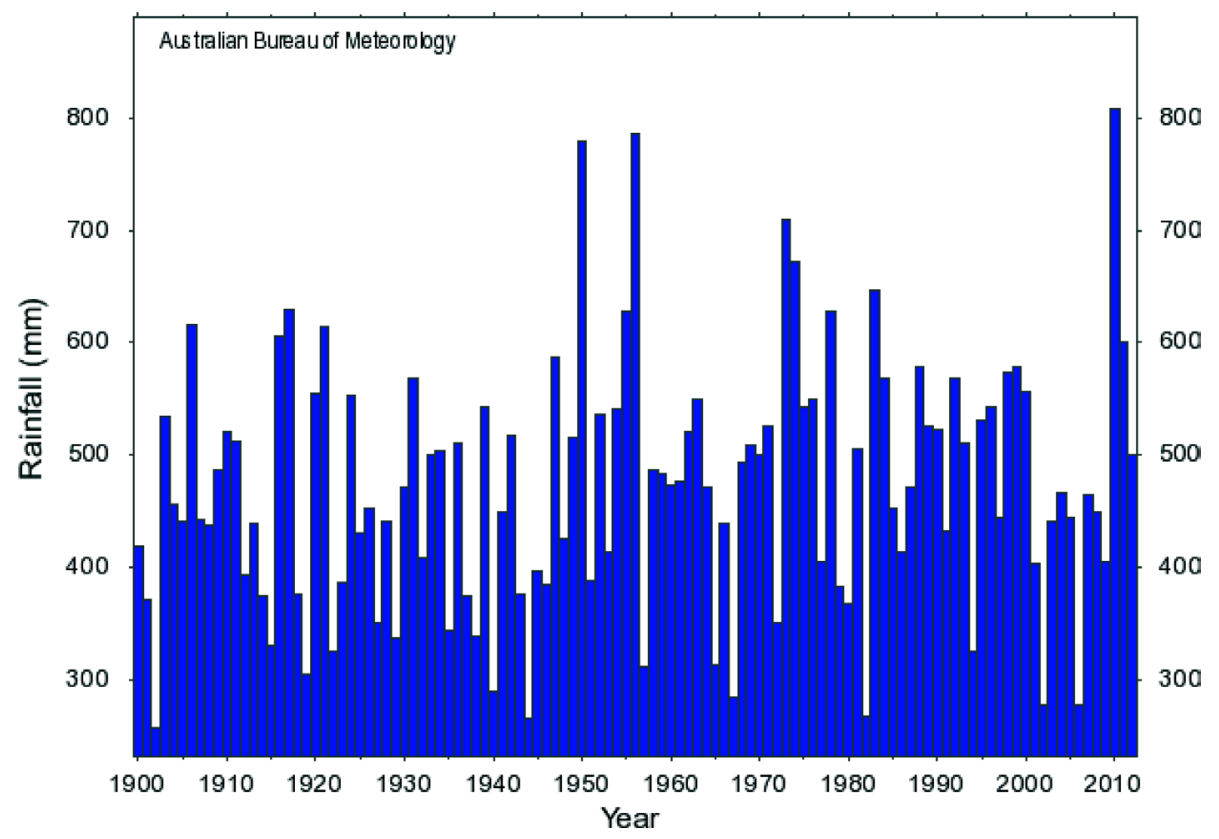

Figure 2: Annual rainfall in the Murray Darling Basin, 1900-2012. Sourced from the Australian Bureau of Meteorology. 
or dying shrimp and yabbies; significantly reduced abundances of native fish; but contained similar abundances of alien fish species (particularly common European carp, Cyprinus carpio)' [7].

The MDBA has suggested that the incidence of blackwater will decrease with more frequent flooding of forests in the Murray Darling because there will be less time for the built up of organic matter on the flood plain [8], and the Basin Plan suggests that blackwater can be mitigated through the delivery of larger volumes of water. These recommendations, however, contradict advice from King et al. [7] that specifically states that increasing the volume of water in the river during a hypoxic blackwater event does not necessarily help to dilute or lessen the severity of the event and thus follow-up floods may increase the severity or prolong the blackwater event [7].

\subsection{Carp management}

The Strategy explained that the pest European carp, Cyprinus carpio, make up an estimated 60\%-90\% of the total fish biomass at many sites, with densities as high as one carp per square metre of river surface area. Through the combination of environmental flows, habitat restoration and carp management, The Strategy suggested that native fish could be returned to $45 \%$ of their pre-European levels.

If stretches of river within the Murray Darling had been allowed to completely dry out during the recent Millennium drought, carp numbers could have been dramatically reduced. Murray cod, and other native species, can survive extended periods of drought by retreating to billabongs, with anecdotal reports that cod can even burrow and hibernate in dry riverbeds. Carp, in contrast, are more likely to become stranded in a dry riverbed and die.

Before the development of extensive water infrastructure, the Murray River occasionally ran dry. For example, there are photographs that support the oral history of the Barmah-Millewa region where Russell McDonald, a local resident, claims: 'Water was never more than two feet deep while we carted timber, and for a long time in autumn 1915 was perfectly dry, the river having stopped running in February or March'.

Then, dams were built so that surplus water could be stored. During the recent protracted Millennium drought (2001-2009), there was a continuous supply of water from the Hume reservoir all the way to the most southern lock on the Murray River at Blanchetown, which is 270-km upstream from the Murray's sea mouth. Below this lock, river levels could not be maintained.

Below the lock at Blanchetown, carp could have been completely eliminated during the Millennium drought by letting the Southern Ocean penetrate the main channel of the river as once happened naturally during drought before construction of the sea dykes. There is a photograph in the State Library of South Australia taken in 1927 of a porpoise caught at Tailem Bend, which is approximately $100 \mathrm{~km}$ from the Murray's sea mouth.

During the worst of the recent Millennium drought, water levels were allowed to fall in Lake Alexandrina to below sea level ostensibly to 'protect' existing freshwater habitat in Lake Alexandrina [9]. This government policy was supported by the significant commercial carp industry in the Lower Murray. Hundreds of tonnes of carp are commercially harvested every year from Lake Alexandrina and converted into plant fertilizer with the commercial catch in the Lower Murray in 2008/2009 reported as 792 tonnes, worth $\mathrm{A} \$ 863,000$ (€681,000 equivalent) [10].

\subsection{Fishways}

Similar to many native Australian fish, Murray cod make an upstream migration to spawn. These migrations were interrupted with the construction of the dams, weirs and locks along the Murray River. According to The Strategy, adding fishways as an intervention in addition to environmental 
flows, habitat restoration and carp management would result in the rehabilitation of native fish communities to about $55 \%$ of pre-European levels.

The Sea to Hume Dam project was a A $\$ 60$ million (€47.69 million equivalent) initiative with the objective of providing a continuous passage for fish from the mouth of the Murray to the Hume Dam, a distance of 2,225 km [11]. The project was due for completion in 2010 at which time it was anticipated that there would be 14 new fishways on 12 weirs and 5 sea dykes along the main stem of the Murray [12].

There has been no evaluation of the overall contribution of the fishways to the rehabilitation of native fish numbers, but it believed that the fishways, all installed by June 2013, are now successfully providing continuous passage to native fish along the main stem of the Murray River for 2,200 km [13].

Millions of dollars have been spent putting fishways into the concrete walls of the five sea dykes immediately behind the Murray River's sea mouth. It is unclear, however, which, if any, native fish species use these structures. In July 2010, the lock in the sea dyke at Goolwa was used to provide passage for Congolli (Pseudaphritis urvillii) to move from the Coorong into Lake Alexandrina [14] presumably because this species could not, or would not, use the fishways installed in the Goolwa and Tauwitchere barrages. Congolli can survive in both sea and freshwater environments, but most estuarine fish species need more than a passage to successfully migrate upstream: they also need a saltwater gradient (see Section 3.2).

\subsection{Cold-water pollution abatement}

Cold-water pollution occurs when water is released from the bottom of deep reservoirs that are thermally stratified. Most native fish species in the Murray Darling, including Murray cod, require relatively warm water temperatures to induce spawning. Studies undertaken during the 1980s and 1990s [15] indicate that frequent large releases of water for irrigation from the Hume and Burrinjuck dams occur in spring and early summer, also critical time for spawning of key native fish species. Releases from Hume dam on the Murray can lower water temperatures by up to $7^{\circ} \mathrm{C}$ [16]. Temperatures downstream of Burrinjuck dam on the Murrumbidgee River seldom approach levels required for spawning of key native species [16].

The expert panel that oversaw development of The Strategy were confident that the abatement of cold-water pollution was the most tangible and achievable of all the proposed interventions, suggesting that this 'threat could be largely removed from the Basin within 10 years' [11]. The Hume and Burrinjuck dams, like most of the dams through the Murray Darling, have the outlets for irrigation positioned at depth creating jets of cold water. Government-commissioned reports [17] have considered different techniques for cold-water abatement including retrofitting with multi-level outlets, artificial destratification through mechanical mixing, trunnions (pipes hinged at the outlet drawing water from different levels), surface pumps (large fan-like propellers that pump water surface water into existing outlets) and submerged rubber curtains to stop the flow of cold water to the outlets.

The Strategy included comment: 'it [cold water pollution abatement] appears to be a clearly definable, tangible, cost-effective intervention that can be completed for the major storages in the Basin within ten years, through a combination of engineering and operating changes'. Many workshops, technical papers and government reports have been written since the launch of The Strategy [18] but none of these contradict the original advice. A study by Sherman [19] estimated that coldwater abatement downstream of Hume dam could be achieved for between $\mathrm{A} \$ 5$ and $\mathrm{A} \$ 20$ million (equivalent to between approximately $€ 4$ and $€ 16$ million) - a fraction of the money already spent 
on implementing The Strategy. However, not a single initiative that will, in practice, address the issue of cold-water pollution downstream of Hume Dam has so far been completed.

In June 2013, the New South Wales Government awarded a contract for cold-water pollution mitigation works at Burrendong Dam on the Macquarie River upstream of Wellington. In the associated media release, NSW Minister for Primary Industries Katrina Hodgkinson said that the company would design, manufacture and install the first cold-water pollution mitigation curtain in the world to enable warmer water from the surface of the dam to be released downstream, rather than cold water from the depths of the storage. In February 2014, a further media release indicated that the $\mathrm{A} \$ 4$ million cold-water pollution works would begin early in the year.

\section{WHAT'S MISSING FROM THE PLANNING?}

There were two glaring omissions in The Strategy, which have carried over into the Basin Plan. First, while it is well known that introduced salmonids are having a significant impact on native fish populations in the MDB through predation and competition, this issue is not canvased in any of the official documents concerned with conservation and rehabilitation of native fish species. Secondly, while The Strategy emphasises the importance of habitat restoration, it completely ignores consideration of the need to restore the Murray River's estuary that once included important breeding grounds and nursery areas for not only Murray cod but also many estuarine and marine fish species including mulloway, Agyrosomus japonicas.

\subsection{Salmonids}

Galaxiids, also known as jollytails, only occur in the southern hemisphere. There are 22 species in Australia, most living in freshwater, and many have been exterminated from rivers and streams in the MDB by the introduction of Salmonids, in particular brown trout, Salmo trutta [20]. Salmonids actively prey on galaxiids and also larger native fish species including trout cod and Macquarie perch [20].

Cold-water releases from the Hume dam that inhibit breeding of native fish species are beneficial to the introduced salmonids. Brown trout, for example, has an optimum temperature range of $4^{\circ} \mathrm{C}-19^{\circ} \mathrm{C}$, significantly cooler than the natural temperature of the Murray River.

Brown trout are native to Europe and were introduced into the Murray Darling, now existing as self-sustaining populations supplemented by hatchery releases. The value of brown trout, and also rainbow trout (Oncorhynchus mykiss), as sport-fish and in aquaculture has overshadowed consideration of their effects on native fauna including native fish, frogs, crayfish and crabs. Cadwallader [20] suggests that some waters be set aside specifically for the management of native fauna and that salmonids be excluded from these waters.

The Basin Plan, ostensibly focused on environmental protection and restoration within the Murray Darling, fails to acknowledge the existence of salmonids and their value as sport-fish or detrimental impact on native fish species. This approach has enabled politicians and government officers to avoid confrontation with the significant recreational fishing lobby.

The Victorian Fly Fisher's Association states on its website that it is an historical association with considerable influence in the promotion of the sport and the propagation of trout [21]. Apparently, the trout and fly-fishing lobby were initially opposed to The Strategy. However, this opposition softened when it was agreed that the issue of cold-water pollution would no longer be addressed in and was removed from the publicity associated with rehabilitation of key demonstration reaches [22]. 


\subsection{Estuary restoration}

The Basin Plan, ostensibly about saving the Murray Darling, does not include any programme of works to restore the Murray River's estuary. The estuary was once dominated by Lake Alexandrina, the central basin of a wave dominated barrier estuary [23]. That was until $7.6 \mathrm{~km}$ of sea dykes, known locally as barrages, were built between the islands towards the southern end of the Lake adjacent to the Murray's sea mouth. The sea dykes were built in the 1930s to prevent inflows from the Southern Ocean. Since then, Lake Alexandrina has been managed as a freshwater reservoir and is arguably the most degraded of all environments within the Murray Darling. Battarbee et al. [24] writing in The Sage Handbook of Environmental Change have commented that the natural state of Lake Alexandrina was tidal, has been incorrectly listed as freshwater in the International Ramsar Convention and that until their natural estuarine character is recognized; it will be difficult to reverse the long-term decline in its ecological health.

The word estuary is absent from the Basin Plan. There is this idea, as an embedded assumption in the Basin Plan, that the Murray River should run fresh to the sea all year, and every year. This idea, however, is not realistic or sustainable. During the Millennium drought, water levels in Lake Alexandrina fell precipitously from $0.85 \mathrm{~m}$ above sea level to $1.10 \mathrm{~m}$ below. There was simply not enough water in upstream storages to supply Lake Alexandrina with freshwater. As the lake waters receded, potential acid sulphate soils were exposed with the pyrite in the soils oxidizing to form sulphuric acid. In an attempt to neutralize the soils, millions of dollars was spent liming the exposed lakebed and channels.

The MDBA claims that the Lower Lakes have always been a freshwater system in effect denying the Murray River as an estuary. This claim, that Lake Alexandrina has always been fresh, goes back to the foundation myths associated with the settlement of South Australia but is inconsistent with the geomorphology of the region. As Bourman et al. [25] explain: 'Originally a vibrant, highly productive estuarine ecosystem of 75,000 ha, characterised by mixing of brackish and fresh water with highly variable flows, barrage construction has transformed the lakes into freshwater bodies with permanently raised water levels; freshwater discharge has been reduced by $75 \%$ and the tidal prism by $90 \%$ '.

Denying the Murray River a functioning estuary has significant implications for restoration of native fish species. For example, there are no longer mulloway in Lake Alexandrina. There was no mention of mulloway in The Strategy, and this species was not listed in any tables or appendices [2]. A mature mulloway can be 25 years old and weigh 90 pounds. Milang, a town on the shores of Lake Alexandrina that was once part of the Murray River's vast estuary, was once home to a thriving mulloway fishery supporting a hundred men and their families routinely sending off several hundred tonnes to the Adelaide and Melbourne fish markets [26]. This fishery collapsed in 1940 when the last of sea dykes was sealed, converting the tidal lake into an artificial freshwater reservoir.

\section{TRENDS AND OBJECTIVES}

A significant limitation for environmental and natural resource management in Australia is the current reliance on expert committees to determine policy. These committees are often also used to guess values that would be better determined through the collection of hard data, or computer simulation modelling. Where quantitative surveys have been undertaken specifically to assess the state of native fish populations, results have sometimes been inconsistent with estimates from other sources, for example the commercial fishery harvest. 


\subsection{Assessing native fish numbers}

One of the difficulties in assessing progress towards restoration of native fish populations in the MDB, now and in the future, is the paucity of available data on actual native fish population numbers. The Strategy claimed native fish populations to be at about $10 \%$ of their pre-European settlement levels. In Australia, pre-European generally refers to the period before 1788. This figure of $10 \%$ is based on the best guess of an expert panel and relates to all native fish rather than particular species [11]. As such, it is scientifically meaningless. Arguably, it would be better for government policy and planning to be based on quantitative assessments. For example, by simulation modelling of the population dynamics of specific native fish species, in particular extrapolating from habitat where salmonids have been excluded and without cold-water pollution.

There have been quantitative surveys of native fish abundance, but the quality of data is suspect [27]. For example, a survey undertaken by The Cooperative Research Centre for Freshwater Ecology (Australia) in conjunction with the New South Wales government in the mid-1990s concluded that: 'A telling indication of the condition of rivers in the Murray region was the fact that, despite intensive fishing with the most efficient types of sampling gear for a total of 220 person-days over a two-year period in 20 randomly chosen Murray-region sites, not a single Murray cod or freshwater catfish was caught' [28]. This result is impossible to reconcile with a commercial harvest for the same region of 26 tonnes of Murray cod in 1995-1996 [27].

The Australian government has spent money on 'auditing' fish numbers, but the auditing only provides a 'snapshot' for specific rivers at particular points in time, with the reporting couched in the subjective criteria of 'good', 'moderate', 'poor' and 'very poor' with the latter criteria dominating [29]. During the most recent audit, fish were sampled at 510 sites that yielded more than 63,000 individuals from 36 species ( 27 natives and 9 aliens), weighing around 4.5 tonnes ( 1.5 tonnes native and 3 tonnes alien). The audit reported that Murray cod recruits were observed at more than half of the 97 sampling sites at which the species was recorded. But the audit makes no determination as to whether the very significant Murray cod re-stocking programme is having a positive impact on overall fish population numbers. In a recent study of the impact of stock enhancement strategies for Murray cod on effective population size, Ingram et al. [30] report that 12.89 million Murray cod have been produced at both government and private (commercial) hatcheries since 1971, but conclude that 'there is no information on the survival of stocked fish to maturity'.

\subsection{Development of the concept of over-allocation of water to agriculture}

The development of a Basin Plan was a requirement of the Water Act 2007. The Act and the Basin Plan are based on the assumption that historical levels of water extraction within the MDB are unsustainable and that this is causing environmental degradation.

This assumption, that has been over-allocation of the water resource, is not questioned or proven in the Basin Plan. For example, consider the following quote from Sheldon et al. [31] that provides the rationale for contemporary government hydrological modelling including the modelling that underpins the Basin Plan: 'Not all the observed ecological impacts can be attributed to hydrological change alone; each catchment has also undergone extensive agricultural development and vegetation clearance, both of which may disturb riverine ecology. However, hydrological change is known to have an overriding and long-lasting effect on ecological processes in large rivers. Thus, it would be fair to attribute a large proportion of the observed ecological change to changes in aspects of hydrology'. 
This concept is then demonstrated by the way of computer modelling, and then the output from the model is used as evidence that there is a problem with water infrastructure development that has caused the hydrological change. Therefore, the argument is circular. Furthermore, ecological response curves are not based on the modelling of empirical data but as explained by Sheldon et al. [31]: 'Ideas for the shape of the ecological response curves came from technical advisory panel discussions'.

The Basin Plan was thus developed with a focus on quantities of water. In particular, the Basin Plan identifies $10,873 \mathrm{GL}$ as the maximum amount of water that can be 'sustainably' extracted from the Basin on average each year. In arriving at a single number of 10,873 GL and then extrapolating to suggest that this means an additional 2,750 GL must be taken from irrigators, the Basin Plan reinforces the perception that irrigators always take a set volume of water from the system. In reality, the amount of water diverted for irrigation is highly variable with most irrigators receiving a small fraction of their license entitlement during periods of drought.

The draft plan acknowledges the highly variable nature of the system in so much as Schedule 1 explains annual inflows to the Basin in the past 114 years have ranged from a high of 117,907 GL in 1956 to only 6,740 GL in 2006. The Basin Plan also notes that this natural variability of flows is important to MDB ecology. Yet, this variability is then ignored in arriving at a single number: a sustainable diversion limit of $10,873 \mathrm{GL}$ is based on a calculated average inflow to the entire MDB of 31,599 GL.

\section{CONCLUSIONS}

In conclusion, billions of dollars of public monies have been spent ostensibly addressing environmental issues in the MDB over the last decade and even more will be spent in the next decade on the Basin Plan. It is unlikely, however, that populations of native fish, including the iconic Murray cod and mulloway, will be restored because key issues, in particular, estuary restoration, cold-water pollution and predation and competition from introduced salmonids, continue to be ignored. It is also unclear whether there has been any net benefit from recent environmental waterings to native fish populations in the Murray Darling because of the increased incidence of blackwater events.

\section{ACKNOWLEDGEMENTS}

This work was funded by the B. Macfie Family Foundation.

\section{REFERENCES}

[1] Murray Darling Basin Commission, Rivers Losses and End of System Flows Fact Sheet, Canberra, 2003. http://www2.mdbc.gov.au/_data/page/20/water_resourcesver2.pdf

[2] Murray Darling Basin Ministerial Council, Native Fish Strategy for the Murray-Darling Basin 2003-2013, Murray Darling Basin Commission, Canberra, 63 pp, 2004.

[3] Koehn, J., Smart partnerships bring back native fish. RipRap, 3-4, pp. 3-4, 2012.

[4] Marohasy, J. \& Abbot, J., Deconstructing the native fish strategy for Australia's Murray Darling catchment. River Basin Management VII, ed. C.A. Brebbia, WIT Press: Southampton, pp. 339-349, 2013. doi: http://dx.doi.org/10.2495/rbm130281

[5] Lyon, J., Resnagging the Murray River. RipRap, 3-4, pp. 24-25, 2012.

[6] Hobson, M., Namoi demonstration reach. RipRap, 3-4, 30 pp, 2012.

[7] King, A.J., Tonkin, Z. \& Lieschcke, J., Short-term effects of a prolonged blackwater event on aquatic fauna in the Murray River, Australia: considerations for future events. Marine and Freshwater Research, 63, pp, 576-586, 2012. doi: http://dx.doi.org/10.1071/mf11275

[8] Murray Darling Basin Authority, 2013-14 Basin annual environmental watering priorities: overview and technical summaries, p. 94, June 2013. 
[9] Brice, C., Literature review on the ecology of fishes of the Lower Murray, Lower Lakes and Coorong. SARDI Publication No. F2010/000031-1, Henley Beach, South Australia, 2010.

[10] Econsearch, Economic indicators for the Lakes and Coorong fishery 2008/09. Primary Industries and Resources South Australia, Adelaide, 47 pp, 2010.

[11] Phillips, B. (ed), Conceptual model to guide investments for restoring native fish in the Murray-Darling Basin. Report by the expert panel convened by the Murray-Darling Basin Commission, 32 pp, 2002.

[12] Craik, W., Murray fishways set world ecosystem restoration standard. Murray Darling Basin Commission, Media Release, 2008.

[13] Towers, I., Personal communication, 8 January 2013, Director, Native Fish Strategy, Murray Darling Basin Authority, Canberra.

[14] News Ltd., Love is in the air in the Lower Lakes - and the government is playing Cupid. July 27, 2010.

[15] Ryan, T., Webb, A., Lennie, R. \& Lyon, J., Status of cold water pollution releases from Victorian dams. Department of Natural Resources and Environment, Melbourne, 72 pp, 2001.

[16] Lugg, A., Eternal winter in our rivers: addressing the issue of cold water pollution. NSW Department of Fisheries, Nowra, 17 pp, 1999.

[17] Sherman, B., Todd, C.R., Koehn, J.D. \& Ryan, T., Modelling the impact and potential mitigation of cold water pollution on Murray cod populations downstream of Hume dam, Australia. River Research and Applications, 23, pp. 377-389, 2007. doi: http://dx.doi.org/10.1002/ rra.994

[18] Koehn, J.D. \& Lintermans, M., A strategy to rehabilitate fishes of the Murray-Darling Basin, south-eastern Australia. Endangered Species Research, 16, pp. 165-181, 2012. doi: http:// dx.doi.org/10.3354/esr00398

[19] Sherman, B.S., Scoping options for mitigating cold water discharges from dams. CSIRO Land and Water, Canberra, p. 130, 2000.

[20] Cadwallader, P.L., Overview of the impacts of introduced salmonids on Australian native fauna. Australian Nature Conservation Agency, p. 69, 1996.

[21] Victorian Fly Fisher's Association, http://www.vffa.org.au

[22] Goulburn Broken Catchment Management Authority, Hollands Creek Demonstration Reach, http://www.gbcma.vic.gov.au/hollandscreek/creek.asp

[23] Ryan, D.A., Heapm, A.D., Radke, L. \& Heggie, D.T., Conceptual models of Australia's estuaries and coastal waterways: application for coastal resource management. Geoscience Australia Record 2003/09, 2003.

[24] Battarbee, R.W., Bennion, H., Gell, P. \& Rose, N., Human impacts on lacustrine ecosystems (Chapter 27). The SAGE Handbook of Environmental Change, ed. J.A. Matthews, SAGE Publications: London, 2012.

[25] Bourman, R.P., Murray-Wallace, C.V., Belperio, A.P. \& Harvey, N., Rapid coastal geomorphic change in the River Murray Estuary of Australia. Marine Geology, 170, pp. 141-168, 2000. doi: http://dx.doi.org/10.1016/s0025-3227(00)00071-2

[26] Olsen, A.M., The Coorong: a multi-species fishery. Part 1, history and development. Fisheries Research Papers No. 22. Department of Fisheries, South Australia, 1991.

[27] Marohasy, J., Myth and the Murray: measuring the real state of the river environment. Institute of Public Affairs, Melbourne, p. 27, 2003.

[28] Harris, J.H. \& Gehrke, P.C., (eds). Fish and Rivers in Stress, The NSW Rivers Survey, NSW Office of Conservation/Cooperative Research Centre for Freshwater Ecology: Sydney/Canberra, p. 293, 1997. 
[29] Davies, P., Stewardson, M., Hillman, T., Roberts, J. \& Thoms, M., Sustainable Rivers Audit 2: The Ecological Health of Rivers in the Murray-Darling Basin at the End of the Millennium Drought (2008-2010), Murray Darling Basin Authority: Canberra, p. 418, 2010.

[30] Ingram, B.A., Hayes, B. \& Rourke, M.L., Impacts of stock enhancement strategies on the effective population size of Murray cod, Maccullochella peelii, a threatened Australian fish. Fisheries Management and Ecology, 18, pp. 467-481, 2011. doi: http://dx.doi.org/10.1111/ j.1365-2400.2011.00798.x

[31] Sheldon, F., Thoms, M.C., Berry, O. \& Puckridge, J., Using disaster to prevent catastrophe: referencing the impacts of flow changes in large dryland rivers. Regulated Rivers: Research \& Management, 16, pp. 403-420, 2000. doi: http://dx.doi.org/10.1002/10991646(200009/10)16:5\%3C403::aid-rrr593\%3E3.0.co;2-3 